\title{
Smithsonian heeds physicists' complaints
}

Washington. The Smithsonian Institution in Washington DC has promised to consult the visiting public, the American Chemical Society (ACS) and other interested parties before implementing changes to a controversial science exhibition at the National Museum of American History that were hammered out at a meeting with angry physicists last month.

The exhibition Science in American Life - a bold pastiche of images on matters such as the conflict between basic research and commercial pressure, the attitude of physicists to the atomic bomb, and the impetus behind the development of the birth control pill - opened last April, financed by a $\$ 5.3$ million grant from the ACS.

But it has come under fierce public attack from another scientific body, the American Physical Society (APS), which says that it exaggerates science's failures and trivializes its accomplishments (Nature, 373, 371. 1995). The APS did not participate in either planning or paying for the permanent exhibition. But it has been noisily attacking the exhibition since its opening.

The APS accuses the show of omitting important achievements such as the space programme and the invention of the transistor, of blaming science for environmental and other social problems, and of being "politically correct" in its emphasis on the under-representation of women and minorities in science.

Some historians involved in the show and outside museum curators have sprung to its defence. Jeff Sturchio, for example, a historian working for the pharmaceutical company Merck, which paid for 100,000 exhibition brochures, describes it as "one of the best shows that has ever been put on to raise serious questions about the role of science in American society".

But after a meeting with APS leaders and museum officials last month, Michael Heyman, secretary of the Smithsonian, told reporters that there would be "some changes which will render the exhibition a lot more balanced".

Heyman declined requests for an interview. But a spokesman for the Smithsonian promised that other groups would be consulted before the changes tentatively agreed at the meeting are implemented. The proposed changes are:

- Revising the opening feature of the exhibition, an audio tape portraying arguments between Ira Remsen, a nineteenth century chemist at John Hopkins University, and his commercially-minded colleague, Constantine Fahlberg. The APS thinks the sequence, intended to highlight the conflict between pure science and commerce, comes over as an unseemly squabble. Heyman is said to agree with this;

- Brightening forbidding lighting and removing barbed-wire fences accompanying descriptions of the Manhattan Project to build the atomic bomb; these were intended to convey an impression of life at the remote and top-secret project sites;

- Changing descriptions of physicists' involvement in the politics of the atomic

\section{IMAGE UNAVAILABLE FOR COPYRIGHT REASONS}

rejected a move by hostile board members to pay up but withdraw its name from the exhibition, the society has publicly supported the show. Indeed, some leading members privately deride the APS's criticisms as "sour grapes" from a body that refused to help finance the exhibition.

"There were many people involved with the show," says Ann Messmore, director of public affairs at the ACS. "Each one has a different opinion." Now that Heyman has spoken, the ACS says it would like to see some changes made. "The comments from the public are wonderful and the kids are excited and thrilled - but if you take a group of scientists to it, they are not going to be happy with every aspect," says Messmore.

The man at the centre of the controversy, Art Molella, chief curator of the exhibition, says the show was not meant for scientists. Their hostility, he says, comes from dashed expectations, namely that science museums and exhibits are commonly conceived as "boosters" for science and technology. He hopes it will rouse the interest of members of the public unimpressed by the science hagiography available elsewhere.

Alan Friedman, director of the New York Hall of Science, says the exhibition breaks new ground by telling the story of how public attitudes to science have changed. "Science exhibits have tended to be very promotional and self-congratulatory," says Friedman. "This is an excellent exhibition, showing how we are coming to understand the complex relationship between science and society. The public will come away feeling more confident that scientists are capable of being introspective about their work."

Richter denies that the APS insists that science should be portrayed heroically. "Of course, science can be misused," he says. "What's missing here is balance."

Also missing is a meeting of minds between scientists and historians. Social historians in particular tend to see their field in terms of conflict, whether between ideas, classes or individuals. The scientists who have attacked the show do not see their own history that way: they think the positive contributions that science, through technology, has made to twentieth century society ought to dominate a show called Science in American Life.

Furthermore, while most museum exhibits portray the scientist with all the dignity of the long-distance runner, this one has him as a player in an ice hockey game without a referee. No prizes for guessing which image schoolchildren prefer: several hundred thousand people are already estimated to have passed through the exhibition.

Colin Macilwain 